\title{
Physico-Chemical Parameters of Water in Holding Tanks of Clarias gariepinus Induced with Ovaprim and Ovulin Hormones
}

\author{
Ukwe, Isaac Oyekutor Kenoye \& Abu, Onisokyetu Monica Godwin
}

Department of Fisheries and Aquatic Environment, Faculty of Agriculture, Rivers State University of Science and Technology, Nkpolu-Oroworukwo, Port Harcourt

\begin{abstract}
The physical and chemical parameters of water in holding tanks of Clarias gariepinus induced with ovaprim and Ovulin hormones were evaluated. The study was done in the hatchery unit of Department of Fisheries, University of Port Harcourt, Choba, Nigeria, and lasted for a period of four weeks. The result obtained showed that dissolved oxygen $(D O)$ ranged between $3.82 \pm 0.88 \mathrm{mg} / \mathrm{l}$ and $6.36 \pm 1.85 \mathrm{mg} / \mathrm{l}$ for ovulin and $3.82 \pm 0 . \mathrm{mg} / \mathrm{l}$ and $5.83 \pm 1.67 \mathrm{mg} / \mathrm{l}$ for ovaprim. Temperature values ranged from $25.89 \pm 0.31^{\circ} \mathrm{C}$ to $26.00 \pm 0.00^{\circ} \mathrm{C}$. Water hardness, chloride, $\mathrm{pH}$, alkalinity and ammonia values in all the treatments were constants and were respectively: $17.10 \pm 0.00 \mathrm{mg} / \mathrm{l}, 30.00 \pm 0.00 \mathrm{mg} / \mathrm{l} 6.50 \pm 0.00,17.100 \pm 0.00$ and $0.001 \pm 0.00 \mathrm{mg} / \mathrm{l}$. Application of the hormones did not impact negatively on the physico- chemical parameters as they were within the required levels recommended for a successful fish reproduction.
\end{abstract}

\section{INTRODUCTION}

The physico-chemical parameters of a body of water is very important to the productivity, growth and survival of the aquatic organisms that are living in the water and thus play an important role in the biology and physiology of the fishes which are part of the organisms living in water (Adebisi, 1981; Owhonda et al.,2007). Bichi et al. (2014) observed temperature values between 25.9 and $30{ }^{\circ} \mathrm{C}$ which was said to be in line with (Ayinla 1988), who reported that the time of interval between the start of embryonic development (fertilization) and hatching, (incubation period) changes with the increase in temperature. Adeniji and Ovie (1982) and Madu (1989) reported that the best temperature range for optimum production of Clarias species is $25-31^{\circ} \mathrm{C}$. Afzal et al. (2007) recommended a temperature range of between $25^{\circ} \mathrm{C}$ to $32^{\circ} \mathrm{C}$ for good performance of fishes. The $\mathrm{pH}$ of the water ranged from 6.1 to 7.6 and this is in agreement with the world health organization International standard for the fresh water (pH 7.08). It also corresponds with works of Huet (1972), USDA (1996) and Robert (2007) who indicate that the best water for cultivation is that which is neutral or slightly alkaline with a $\mathrm{pH}$ range of 7 to 8 . The value for dissolved Oxygen content of water observed by Bichi et al., (2014) ranged from 5.0mg/l and these agreed with those of Ufodike and Garba, (1992) who reported that a minimum constant value of $4.0 \mathrm{mg} / \mathrm{l} \mathrm{DO}$ is adequate for most species and stages of aquatic life. Brain (2006) and Ita et al., (1995) reported that increased DO level is needed to support an increase in metabolic rates and reproduction.

According to Valeta (2013) increase in temperature is known to speed up metabolism through biochemical activity stimulated by heat energy (Beveridge and McAndrew, 2000) which results in enhanced development of the fish eggs. There is potential for increased temperature between 25 and $29{ }^{\circ} \mathrm{C}$ to significantly reduce hatching period and increase hatchability and fry survival. For example, temperature is known to be the main environmental factor governing fish egg development (Blaxter 1992). Temperature affects certain morphological features, hatching rate and larval behavior. In a research carried out by Bhujel et al, (2000), temperature influenced egg development and hatching in O. niloticus, Tilapia zillii (Omotosho 1988) common carp, Cyprinus carpio, (El-Gamal, 2009), and Cod, Gadus morhua (Page and Frank, 1989; Geffen et al., 2006).

Physicochemical parameter such as $\mathrm{pH}$ has been considered as one of the major factors affecting the hatchability and fertility of fish egg. Yang et al., (2011) in an experiment reported that hatching was first observed at $\mathrm{pH} 10$, beginning at $27 \mathrm{~h}$ after fertilization and ending at the $31 \mathrm{~h}$. A clear difference was observed between hatching times, ranging from 31 to $64 \mathrm{~h}$ and increasing in order with decreasing pH. Yang et al., (2011) in similar experiment with the Catfish, Silurus asotus reported 
hatching rates in acid solutions to be higher than those in alkaline solutions which was considered to be a wide $\mathrm{pH}$ range for hatching compared to other fish species. Yang et al., (2011) observed that eggs could be fertilized at $\mathrm{pH} 3-12$ while in a hatching experiment, mortality was first observed at $\mathrm{pH}$ 13, when all fertilized eggs died within 8 min, followed by pH 2 (30 min), pH 12 (60 min), pH 3 (4 h), and $\mathrm{pH} 11(5 \mathrm{~h})$. This was attributed to high level of acidity which must have destroyed the viability of the eggs before, during and after hatching.

Many reports of hatching failure under such acidic conditions have been published. For example, Trojnar (1977) reported that deformations and death of white sucker C. commersoni embryos occurred at pH 5.0. Mount (1973) found that deformations of fathead minnow Pimephales promelas eggs took place at pH 5.9. Johansson and Milbrink (1976) reported that the embryonic development of roach and perch stopped at a pH lower than 4.6.

Since good water quality is essential to hatching success of fish in aquaculture, this study therefore investigate the water quality parameters in holding tanks of C.gariepinus induced with Ovaprim and Ovulin .

\title{
2. Materials ANd Methods
}

\section{Determination of Water Physico-Chemical Parameters}

The physico -chemical parameters measured were dissolved oxygen (DO), temperature, $\mathrm{pH}$, alkalinity, chloride and ammonia. The $\mathrm{pH}$ was measured with $\mathrm{pH}$ meter and controlled by the addition of alkaline if necessary.

\section{Dissolved Oxygen}

A glass-stoppered DO bottle was filled with water and allowed to overflow for three minutes. No air bubbles were allowed in the bottle by inclining the bottle slightly and inserting the stopper with a quick thrust. The stopper was carefully removed from the bottle. $0.5 \mathrm{ml}$ each of Winkler solution 1 and solution 2 reagents were added to the contents of the bottle and was thoroughly shaken to mix properly. A flocculent precipitate was formed and allowed to settle. Also, $0.5 \mathrm{ml}$ of concentrated $\mathrm{H}_{2} \mathrm{~S} 04$ was added to liberate the iodine equivalent of dissolved oxygen in the titration with the thiosulphate (APHA, 1998). The $5 \mathrm{ml}$ content was carefully put in a mixing bottle, five droplets of sodium thiosulphate (Standard Solution) were added drop by drop to the contents of the mixing bottle.

\section{Temperature}

A mercury thermometer calibrated in degree centigrade $\left(0-100^{\circ} \mathrm{C}\right)$ was used in the determination of water temperature. The thermometer scale was read off after dipping into water. When immersed in the water column it was allowed to stand for 5 minutes and reading was taken immediately it was removed. An average record was taken after taking three measurements.

\section{Hydrogen ion Concentration (pH)}

The $\mathrm{pH}$ value of the water was determined in the laboratory using a $\mathrm{pH}$ meter EIL model 720 made by Hach of Japan. The $\mathrm{pH}$ was determined by simply dipping the electrode into a $200 \mathrm{mls}$ of water that had been stirred and the reading was subsequently read off the meter. The mean of two of such readings was recorded as the $\mathrm{pH}$ of the water.

\begin{abstract}
Alkalinity
The total alkalinity value was determined from the titration of $0.02 \mathrm{~m}$ tetraoxosulphate (vi) acid $\left(\mathrm{H}_{2} \mathrm{SO}_{4}\right)$ until methyl orange indicator colour changed from yellow to pink.100ml of the water sample was transferred into a $250 \mathrm{ml}$ conical flask followed by 2 drops of methyl orange indicator and titrated with $0.02 \mathrm{~N} \mathrm{H}_{2} \mathrm{SO}_{4}$ until there was a colour change from yellow to pink at the end point of the titration. This was repeated twice and the average concordant titre values were used to calculate the total alkalinity expressed in $\mathrm{mg} / \mathrm{l}$.
\end{abstract}

\section{Total Hardness of Water}

Fifty $(50 \mathrm{ml})$ of the sample solution was poured into the beaker and $1 \mathrm{ml}$ of ammonia buffer solution $(0.5 \mathrm{~N})$ and two to three drops of Eriochromo Black with 0.1M EDTA solution were added and titrated to the end point of blue colour. The Total Hardness were similarly obtained for all the samples collected from the eighteen stations/tanks. 
Physico-Chemical Parameters of Water in Holding Tanks of Clarias gariepinus Induced with Ovaprim and Ovulin Hormones

Total Hardness $(\mathrm{mg} / \mathrm{l})=\frac{0.01 \times \text { titre } \times 40.1 \times 1000}{\text { Vol. of sample }}$

\section{Chloride}

Fifty milli liter $(50 \mathrm{ml})$ of samples and blank were measured into a conical flask and 3 drops of mixed indicator above were added into the sample and the blank. Then $1 \mathrm{ml}$ of Nitric acid was added into each of the flasks (representing 18 tanks) using dropping pipette until the solution turned pale yellow. Mercuric II Nitrate was titrated against each solution until a colour change occurred. The endpoint of titration was the appearance of a blue colour.

\section{Data Analysis}

Data obtained from each treatment were compared by two way ANOVA test to determine the significant differences $(\mathrm{p}<0.05)$ in reproductive performance parameters and physico-chemical parameters such as dissolved oxygen, temperature, Ammonia, chloride, total hardness and $\mathrm{pH}$ using Turkey Honest significant difference at $95 \%$ probability.

\section{RESUlts}

Table 4.1 shows the physico-chemical parameters of the water in the treatment tanks during the experimental period. Dissolved oxygen (DO) in the respective treatments $(50,75$ and $100 \%)$ varied from $3.82 \pm 0.88 \mathrm{mg} / \mathrm{l}$ to $6.36 \pm 1.85 \mathrm{mg} / \mathrm{l}$ with some levels of slight significant difference for ovulin $(\mathrm{p}<0.05)$ while that of ovaprim varied from $3.82 \pm 0 . \mathrm{mg} / \mathrm{l}$ to $5.83 \pm 1.67 \mathrm{mg} / \mathrm{l}$ (Table 1). Dissolved oxygen decreases with increase in concentration of hormone in both ovulin and ovaprim treated water. Dissolved oxygen fluctuated in value between week 1 to 4 with the highest $(6.76 \pm 1.84 \mathrm{mg} / \mathrm{l})$ and the lowest value $(4.00 \pm 0.59 \mathrm{mg} / \mathrm{l})$ observed in weeks 2 and 4 for ovulin treated tank. Dissolved oxygen also fluctuated with the highest value $(6.20 \pm 1.24)$ and the lowest value $(3.63 \pm 0.53 \mathrm{mg} / \mathrm{l})$ observed in weeks 2 and 4 for ovaprim (Figure 1). Dissolved oxygen showed significant difference between weeks $(\mathrm{p}<0.05)$. Temperature values vary slightly from $25.89 \pm 0.31^{\circ} \mathrm{C}$ to $26.00 \pm 0.00^{\circ} \mathrm{C}$ with the highest value observed in treatment $3(100 \%)$ for ovulin treated tank but fairly constant in ovaprim treated tank with temperature range of $25.80 \pm 0.39$ to $25.89{ }^{\circ} \mathrm{C}$ (Table .1).

The weekly temperature value also show some degrees of consistency (Figure 2).Temperature value showed significant difference $(\mathrm{p}<0.05)$ between weeks. Water hardness in all the treatments are constants/uniform $(17.10 \pm 0.00)$. Figure 3 also shows that the weekly water hardness were also uniform $(17.100 \pm 0.00)$. Chloride values were uniform, $30.00 \pm 0.00 \mathrm{mg} / \mathrm{l}$ without significant difference $(\mathrm{p}<0.05)$. $\mathrm{pH}$ values were also the same $6.50 \pm 0.00$ which is slightly acidic in the ovulin and ovaprim treated tanks without significant difference (Tables 1; Figures 4, and 5 ). Alkalinity values were uniform at $17.100 \pm 0.00$ in the ovulin and ovaprim treated tanks without significant difference (Table 1 and Figure 6). Ammonia values were constant throughout the study period in the ovulin and ovaprim treated tanks without significant difference (Tables 1 and Figure 7).

Table 4.1. Effect of Ovulin (A) and Ovaprim (B) on the physico-chemical properties of water. (means $\pm S D)$

\begin{tabular}{|c|c|c|c|}
\hline \multirow{2}{*}{$\begin{array}{l}\text { Variables } \\
\text { Ovulin }\end{array}$} & \multicolumn{3}{|c|}{ Concentration (\%) } \\
\hline & 50 & 75 & 100 \\
\hline Dissolved oxygen $(\mathrm{mg} / \mathrm{l})$ & $6.36 \pm 1.85^{\mathrm{a}}$ & $5.71 \pm 1.24^{b}$ & $3.82 \pm 0.88^{\mathrm{c}}$ \\
\hline Temperature $\left({ }^{\circ} \mathrm{C}\right)$ & $25.89 \pm 0.31^{\mathrm{a}}$ & $25.89 \pm 0.31^{\mathrm{a}}$ & $26.00 \pm 0.00^{b}$ \\
\hline Hardness (mg/l) & $17.10 \pm 0.00^{\mathrm{a}}$ & $17.10 \pm 0.00^{\mathrm{a}}$ & $17.10 \pm 0.00^{\mathrm{a}}$ \\
\hline Alkalinity (mg/l) & $17.10 \pm 0.00^{\mathrm{a}}$ & $17.10 \pm 0.00^{\mathrm{a}}$ & $17.10 \pm 0.00^{\mathrm{a}}$ \\
\hline Chloride (mg/l) & $30.00 \pm 0.00^{\mathrm{a}}$ & $30.00 \pm 0.00^{\mathrm{a}}$ & $30.00 \pm 0.00^{\mathrm{a}}$ \\
\hline $\mathrm{pH}$ & $6.50 \pm 0.00^{\mathrm{a}}$ & $6.50 \pm 0.00^{\mathrm{a}}$ & $6.50 \pm 0.00^{\mathrm{a}}$ \\
\hline Ammonia (mg/l) & $0.00 \pm 0.00^{\mathrm{a}}$ & $0.00 \pm 0.00^{\mathrm{a}}$ & $0.00 \pm 0.00^{\mathrm{a}}$ \\
\hline \multicolumn{4}{|l|}{ Ovaprim } \\
\hline Dissolved oxygen $(\mathrm{mg} / \mathrm{l})$ & $5.83 \pm 1.67^{\mathrm{a}}$ & $4.95 \pm 1.29^{b}$ & $3.82 \pm 0.63^{\mathrm{c}}$ \\
\hline Temperature $\left({ }^{\circ} \mathrm{C}\right)$ & $25.80 \pm 0.39^{\mathrm{a}}$ & $25.87 \pm 0.33^{\mathrm{a}}$ & $25.89 \pm 0.31^{\mathrm{b}}$ \\
\hline Hardness (mg/l) & $17.10 \pm 0.00^{\mathrm{a}}$ & $17.10 \pm 0.00^{\mathrm{a}}$ & $17.10 \pm 0.00^{\mathrm{a}}$ \\
\hline Alkalinity (mg/l) & $17.10 \pm 0.00^{\mathrm{a}}$ & $17.10 \pm 0.00^{\mathrm{a}}$ & $17.10 \pm 0.00^{\mathrm{a}}$ \\
\hline Chloride (mg/l) & $30.00 \pm 0.00^{\mathrm{a}}$ & $30.00 \pm 0.00^{\mathrm{a}}$ & $30.00 \pm 0.00^{\mathrm{a}}$ \\
\hline $\mathrm{pH}$ & $6.50 \pm 0.00^{\mathrm{a}}$ & $6.50 \pm 0.00^{\mathrm{a}}$ & $6.50 \pm 0.00^{\mathrm{a}}$ \\
\hline Ammonia (mg/l) & $0.00 \pm 0.00^{\mathrm{a}}$ & $0.00 \pm 0.00^{\mathrm{a}}$ & $0.00 \pm 0.00^{\mathrm{a}}$ \\
\hline
\end{tabular}


Different superscript in the same column shows significant difference $(P<0.05)$
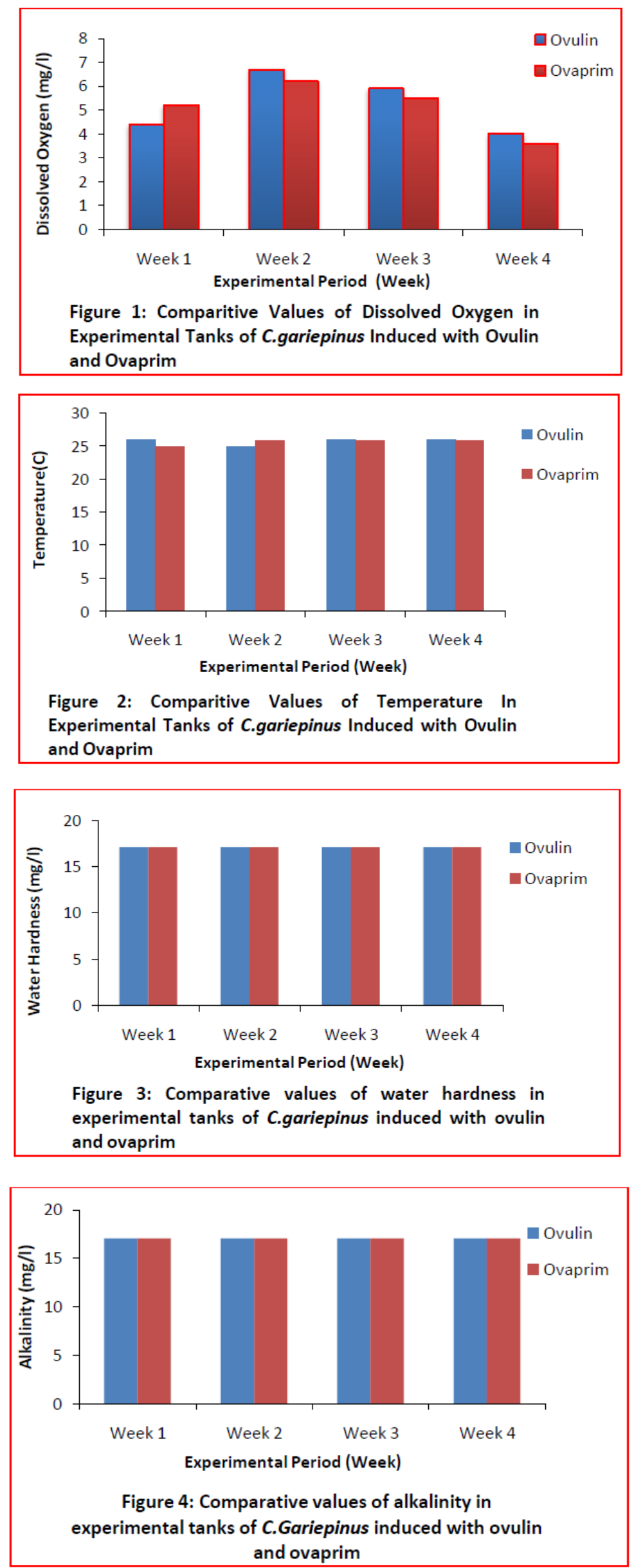

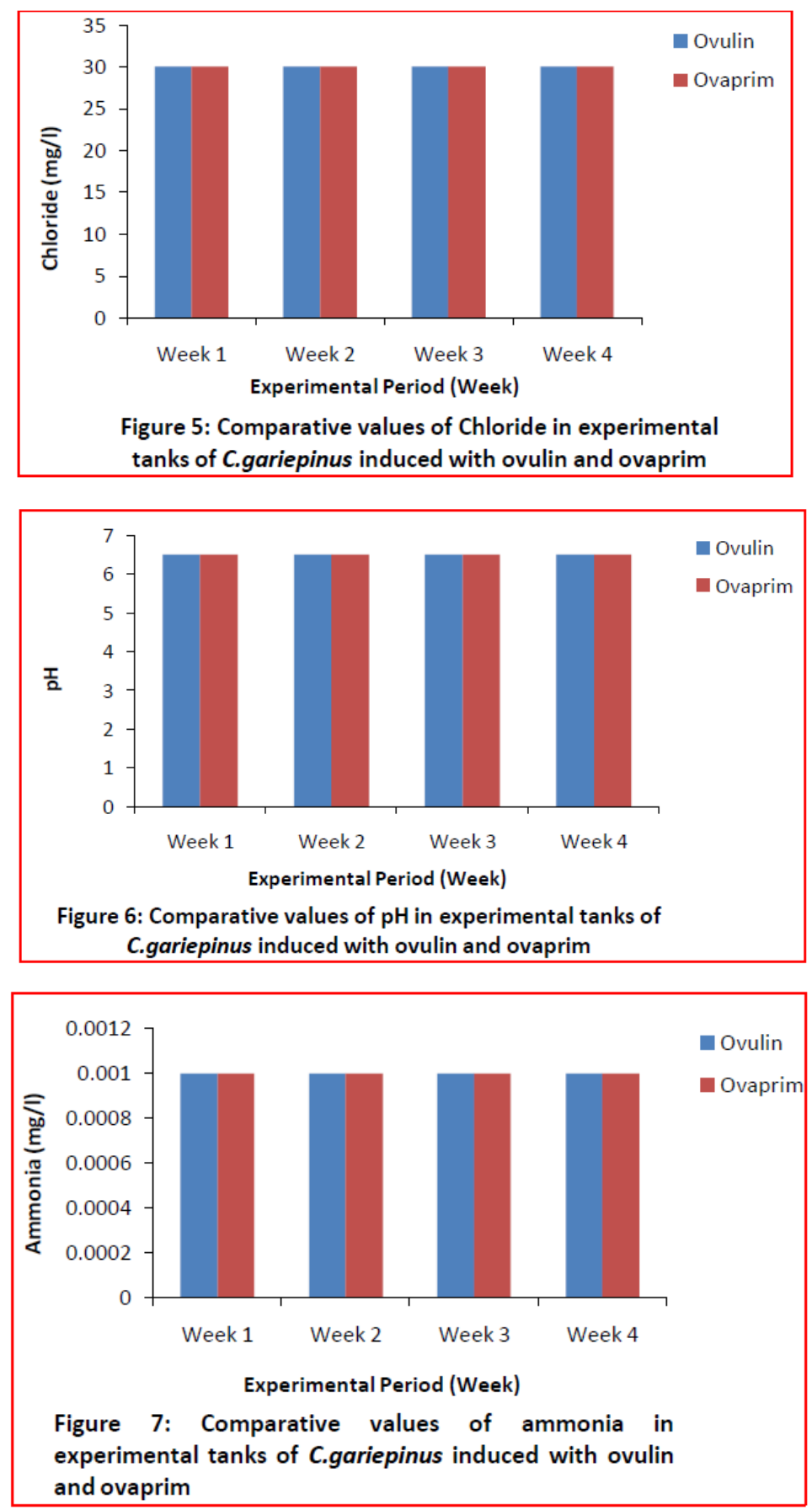

\section{DisCUSSION}

The dissolved oxygen (DO) obtained in this studys were within the required levels recommended for a successful fish reproduction and in agreement with FAO (1996) except the fall in dissolved oxygen $3.82 \pm 0 . \mathrm{mg} / \mathrm{l}$ compared to $6 \mathrm{mg} \mathrm{L}^{-1}$ recommended by FAO but this can be attributed to the securely locked indoor hatchery used for the study. The value for dissolved Oxygen content also agreed with those of Ufodike and Garba (1992) that reported a minimum constant value of $4.0 \mathrm{mg} / \mathrm{l} \mathrm{DO}$ is adequate for most species and stages of aquatic life. Brain (2006) and Ita et al, (1995) reported that increased DO level is needed to support an increase in metabolic rates and reproduction.

Temperature $\left({ }^{\circ} \mathrm{C}\right)$ values recorded in this experiment and this is in line with Ayinla (1988), who reported that the time interval between the start of embryonic development (fertilization) and hatching, (incubation period) changes with the increase in temperature, Adeniji and Ovie (1982) and Madu (1989), reported that the best temperature range for optimum production of Clarias species is 25-31 ${ }^{\circ} \mathrm{C}$. Afzal et al. (2007) recommended a temperature range of between 25 to $32{ }^{\circ} \mathrm{C}$ for good performance of fishes. The metabolism of cold blooded organisms (Poikilotherms) is dependent on 
temperature as well as the solubility of dissolved oxygen and the density and viscosity of the water. Therefore, the survival, growth and behaviour of aquatic organisms are dependent on temperature. Sikoki and Veen (2004) noted that fish and many other aquatic organisms grow best at temperatures between $25-32^{\circ} \mathrm{C}$ especially in the tropic. Guy (1992) also reported that temperatures between $30-$ $35{ }^{\circ} \mathrm{C}$ are tolerated by fish and many other aquatic organisms but above this range, aquatic life is threatened. According to Abdu raheem et al.(2012) the temperature range of 25.70 to $27.00{ }^{\circ} \mathrm{C}$ (mean $26.40{ }^{\circ} \mathrm{C}$ ) recorded throughout their experiment was higher than $22{ }^{\circ} \mathrm{C}$ which Viveen et al.(1986) observed for $C$. gariepinus that exhibited latency period in excess of 15 hours, while Zonnelveld et al. (1988) obtained their best results at $25^{\circ} \mathrm{C}$.

$\mathrm{pH}$ values obtained in this study were uniform at $6.50 \pm 0.00$ which is slightly acidic in the ovulin and ovaprim treated tanks. This is in line with the $\mathrm{pH}$ ranged from 6.1 to 7.6 reported by Bichi et al. (2014) which was attributed to environmental factors and also in agreement with the world health organization. International standard for the fresh water is $\mathrm{pH}$ 7.08. It also corresponds with works of Huet (1972), USDA (1996) and Robert (2007), which indicate that the best water for cultivation is that which is neutral or slightly alkaline with a $\mathrm{pH}$ range of 7 to 8 .

The $\mathrm{pH}$ of 7.00 to 8.00 was within normal range for culture fishes (Viveen et al., 1986). Woynovorich and Horvath (1980) stated that a number of environmental factors such as temperature, $\mathrm{pH}$, dissolved oxygen and calmness play decisive role in ovulation and that temperature is of vital importance. Yang et al., (2011) in an experiment reported that hatching was first observed at $\mathrm{pH} \mathrm{10,} \mathrm{beginning} \mathrm{at} 27 \mathrm{~h}$ after fertilization and ending at the $31 \mathrm{~h}$. A clear difference was observed between hatching times, ranging from 31 to $64 \mathrm{~h}$ and increasing in order with decreasing $\mathrm{pH}$. Yang et al., (2011) in similar experiment with the Catfish, Silurus asotus reported hatching rates in acid solutions to be higher than those in alkaline solutions which was considered to be a wide $\mathrm{pH}$ range for hatching compared to other fish species. The $0.001 \pm 0.00$ observed for ammonia in this study is in disagreement with the $0.50 \mathrm{mg} / \mathrm{l}$ reported by Abdu raheem et al. (2013). This could be attributed to difference in environmental and physiological factors.

\section{Conclusion}

Application of both ovulin and ovaprim in spawning of C.gariepinus did not impact negatively on the water quality parameters except in dissolved oxygen, which can be augmented with the use of aerators. The results of this research will therefore be important to aqua culturists in both semi intensive and intensive systems in improving water quality for production of adequate quality fingerlings required for commercial farming of Clarias gariepinus in Nigeria and other developing countries. It will also help farmers improve the hatchability of Clarias gariepinus eggs and survival rate of Clarias gariepinus fry by routinely monitoring temperature and other physico-chemical parameters to avoid mortality during hatchery operations.

\section{REFERENCES}

[1] Abdulraheem, S.O.,Otubusin,O.T., Agbebi,O.,Olowofeso, K. A. \& Adeyemi, A.S.S. (2012).Induced Breeding of African Catfish (Clarias gariepinus) Under Varying Brood Stock Ratios'.Global Journal of Science Frontier Research Agriculture and VeterinarySciences, 12(8)1.

[2] Adebisi, A.A.(1981). The physic-chemical Hydrobiology of seasonal upper river, Hydrobiology, 79:157-165.

[3] Adeniji, H.A \& Ovie S. L. (1982). Study and appraisal for water quality of the Asaoli and Niger rivers. NIFFR Annual report pp. 15-20.

[4] Afzal, M., Rab, A., Akhtar, N., Khan, M.F., Barlas, A. \& Qayyum, M. (2007). Effect of organic and inorganic fertilizers on the growth performance of bighead Carp (Aristichthys nobilis) in polyculture system. International journal of Agriculture and Biology, 9(6): 931-933.

[5] Aiyelari, T A, Adebayo I A \& Osiyemi, A S (2007). Reporting fitness of stressed and steroids. Fish Physiol. Biochem. 14, 237-246. Animal Biology, 1 (5): 78-81.

[6] Ayinla,O.A.(1988).Nutrition and Reproductive performance of Clarias gariepinus (Burchell 1822), Ph.D Thesis, Department of wildlife and fisheries Management, University of Ibadan Nigeria, pp: 433. 
[7] Beveridge, M.C.M, \& Mc Andrew, B.J. (2000). Tilapias: Biology and Exploitation. Kruwer Academic Press Publishers. Dordrecht, the Netherlands. p. 505

[8] Bhujel, C.R., Luang, K \& Thani, P. (2000). A Review of Strategies for the Management of Nile Tilapia (Oreochromis Niloticus) Broodfish in Seed Production Systems, Especially HapaBased Systems. Thailand.

[9] Bichi, A.H., Isyaku, S., Danba, E.P., Kurawa, I.A \& Nayawo, A.A. (2014). Effect of Brood Stock Size On Egg Fertilization, Hatchability and Fry Survival Rate of African Catfish ( Clarias gariepinus ). Bayero Journal of Pure and Applied Sciences, 7(2): 150 - 154 .

[10] Blaxter, J.H.S. (1992). The effect of temperature on larval fishes. Netherland Journal of Zoology, 42:336-357

[11] Brain, O., (2006). Dissolved Oxygen Environmental quality, 84: 18766.

[12] El-Gamal,A.E.(2009). Effect of Temperature on Hatching and Larval Development and Mucin Secretion in Common Carp, Cyprinus carpio (Linnaeus, 1758). Global Veterinaria 3(2):80-90.

[13] FAO(1996). Artificial Reproduction and Pond Rearing of the African Catfish (Clarias gariepinus) in Sub-Saharan Africa-A Handbook. Food and Agriculture Organization of the United Nations, Fisheries and Aquaculture Department Rome, Italy Pages: 73.

[14] Geffen, A.J, Fox, C.J, Nash, R.D.M. (2006). Temperature-dependent development rates of cod (Godus morhua) eggs. Journal of Fish Biology. 69:1060-1080.

[15] Huet, M., (1972). Textbook of fish culture breeding and cultivation of fish translated by $\mathrm{H}$. Kohn fishing news (books) Ltd, farnham, survey England pp 436.

[16] Ita, E.O. Balogun, J.K .\& Adimula,A.B.,(1995).A preliminary report of pre- impoundment of fishe survey of Goronyo reservoir Sokoto. NIFFR Annual report Pp35-38.

[17] Johansson,N \& Milbrink, G.(1996). Some effects of acidified water on the early development of Roach and Perch.Water Resources Bulletin, American Water Resources Association. 12 (1).

[18] Madu, C.T. (1989). Hatchery management of the mudfish (Clarias anguilaris L) PhD. Thesis.

[19] Omotosho, J.S.(1988).The Development of Eggs and Larvae in Tilapia zillii (Gervais). Nigerian Journal of Science. 22(12):24-28.

[20] Owhonda, K. N., Akinrotimi, O. A., Ansa, E. J.,Edun, O. M., Anyanwu, P. E., Opara, J. Y., \& Onunkwo, D. O. (2007). Wet season variations in some physiochemical parameters of brackish water fish ponds and main channels in Buguma, Rivers State, Nigeria. Journal of Fishery International, 2(3), 255-259.

[21] Page, F.H, Frank, K.T.(1989). Spawning time and egg stage duration in Northwest Atlantic haddock (Melanogrammus aeglefinus) stocks with emphasis on Georges and Browns Bank. Canadian Journal of Fisheries and Aquatic Science, 46(1): 68-81

[22] Robert, C.S., (2007). Water quality consideration for Aquaculture. Journal of Animal Ecology, $2: 1-15$.

[23] Sikoki, F.D. \& J.V. Veen, 2004. Aspects of water quality and potential for fish production [ of Shiroro Reservior, Nigeria. Livestock Syst. Sustainable Development., 2: 1-7.

[24] Ufodike, E.B. \& Garba, A.J. (1992). Seasonal variation in Limnology and productivity of a tropical highland fish pond in Jos Plateau, Nigeria journal of Aquatic sciences, 7:29-34

[25] USDA, US Department of Agriculture (1996). Aquaculture outlook, the rev.4: 26- 28.

[26] Valeta, J. S.(2013).Temperature-dependent egg development rates, hatchability and fry survival rate of Lake Malawi Tilapia (Chambo), (Oreochromis karongae) (Pisces: Cichlidae).International Journal of Fisheries and Aquaculture,5(4),55-59.

[27] Viveen, W. J. A. R., C. J. J. Richter, P.G.W.J. Van, Ordt, J. A. L. Janseen, \& Huisman. A. (1986). Practical manual for the culture of the African catfish (Clarias gariepinus).The Netherlands Ministry for Development Corporation, Section for Research and Technology, The Hague, The Netherlands, 128 pp 
[28] Woynarovitvh, E \& Horvath, L.(1980). La Reproduction Artificielle des poisons en eau Chaude: Manuel de Vulgariztion, Food and Agricultural Organization Document. Techpeches. Volume 201; page 191.

[29] Yang, G, Sun-Gyu K. \& Jeong-Yeol, L.(2011). Effects of pH on Fertilization and the Hatching Rates of Far Eastern Catfish (Silurus asotus). Fisheries and Aquatic Science. 14(4), 417-420.

[30] Zonneveld, I.S. \& Surasana, E.(1988). Ecosystem invento- ryhegetation survey (Komering basin, Sumatra), ITC Journal 1, 67-75.

\section{AUTHOR'S BIOGRAPHY}

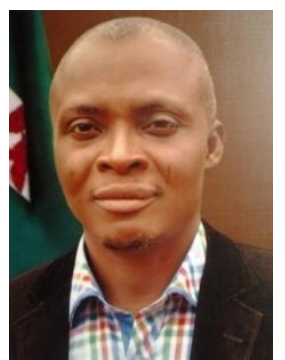

Ukwe, Isaac Oyekutor Kenoye, is a practical fish farmer with over six (6) years experience. He is the Managing Director and C.E.O of IDI-ONYANA FARMS NIG. LTD. He is a politician, he has been three (3) times Secretary and one time Chairman in Abua/Odua Local Government Area of Rivers State, Nigeria. He has a B.Sc Degree in Chemistry and a Post Graduate Diploma (PGD) in Fisheries and Aquatic Environment from Rivers State University of Science and Technology, Nkpolu-Oroworukwo, Port Harcourt, Nigeria. He is currently an M.Sc student in Aquaculture in the same University. He is married to Mrs Idiowa. $\mathrm{O}$. Ukwe and the marriage is blessed with six children.

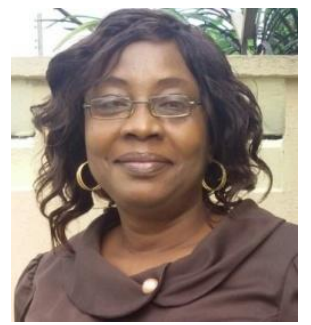

Dr. (Mrs.) O. M. G. Abu, is a Senior Lecturer in the Department of Fisheries, Faculty of Agriculture, University of Port Harcourt. She is a renowned expert, specializing in Aquaculture, Catfish Fingerling Production, Establishment of Fish Farms and Fish Nutrition and Processing. She is especially noted for her efforts in giving quality supervision to students in their research projects for good project work, improving learning and bringing the project to a good conclusion adding to knowledge. Dr. Abu has carried out several researches and has several publications in international and local journals covering diverse areas in fisheries. Dr Abu's current research and interests revolve around the Development of best aquaculture practices for healthy fish production and food safety. Her past roles include being the Former Director of Fisheries, Rivers State Agricultural Development Programme, Rivers State Nigeria, Personal Assistant to Honorable Commissioner for Agriculture, Rivers State Nigeria. Rivers State Facilitator for Fisheries in National Special Programme for Food Security, a World Bank Sponsored Project. Fisheries Consultant, International Institute for Tropical Agriculture (IITA) Onne, Managing Director SAMMANI CONSULTS, a capacity building outfit on agriculture and has trained many members of agriculture cooperatives. She has consulted for many fish farms including the famous CANABU FARMS in Rivers State. Dr. Abu is the founder of Divine Love Project, an organization that supports less privileged and motherless babies. 